\title{
Zákulisí výzkumu na téma percepce atraktivity lidského obličeje $v$ kontextu stárnutí - strategie v rozhodování, úvahy a pozorování
}

\author{
Lada Pavlíková \\ Katedra antropologie Fakulty filozofické Západočeské univerzity v Plzni, Sedláčkova 15, 30614 Plzeň \\ Do redakce doručeno 14. července 2014; k publikaci přijato 15. ř́ijna 2014 \\ BACKSTAGE OF THE RESEARCH ON PERCEPTION OF HUMAN FACIAL ATTRACTIVENESS IN THE CONTEXT \\ OF AGING - THE DECISION MAKING STRATEGY, CONSIDERATIONS AND OBSERVATIONS
}

\begin{abstract}
The article seeks to capture the background of a research focused on the attractiveness of the human face in the context of aging. Starting with a description of the decision making process about what methodological way to proceed; through effective strategies during volunteers recruiting for facial photos making; detection of the problem in establishing a neutral facial expression in older age and the sampling of respondents construction, the author gets to describe the course of the actual investigation. The aim of this contribution is not to introduce the reader to quantitatively tuned results arising from the statistical types of analyzes. The aim is to introduce them to the "way", after which the author within the research decided to go, to show the reasons for doing so and outline how the initial barrier on the way to transform to the "building material", from which it is eventually built.
\end{abstract}

KEY WORDS human face; attractiveness; sympathy; aging; neutral facial expression

ABSTRAKT Článek se snaží postihnout pozadí výzkumu soustředěného na atraktivitu lidského obličeje v kontextu stárnutí. Počínaje popisem procesu rozhodování jakou metodologickou cestou se ubírat, přes účinné strategie při náboru dobrovolníků k fotografování, odhalení problému v nastolení neutrálního výrazu ve vyšším věku a konstrukci výběrového souboru respondentů, se autorka dostává $\mathrm{k}$ průběhu vlastního šetření. Cílem tohoto př́spěvku není seznámit čtenáře s kvantitativně laděnými výsledky plynoucími ze statistických typů analýz. Cílem je představit jim „cestu“, po které se autorka v rámci výzkumu rozhodla jít, ukázat důvody, které jí k tomu vedly a nastínit, jak původní překážky na této cestě přeměnit ve „stavební materiál“, ze kterého je nakonec vystavěna.

KLÍČOVÁ SLOVA lidský obličej; atraktivita; sympatie; stárnutí; neutrální výraz

\section{ÚVOD}

Chceme-li se zabývat tématem percepce atraktivity lidského obličeje v kontextu stárnutí, je nejprve, jako ostatně v př́ípadě jakéhokoliv jiného výzkumného „snaženi“, zapotřebí provést rešerši co největšího množství dostupných sekundárních dat o výzkumu s danou tematikou. Počínaje odhalením významu lidského obličeje (především z evoluční a sociální perspektivy), přes porozumění složitému procesu jeho percepce, pro- studování doposud známých teorií atraktivity, až po postupné rozkrývání různorodých aspektů stárnutí. Nedílnou součástí je na počátku rovněž analýza metodologických postupů, které již ve studiích o atraktivitě lidského obličeje byly s úspěchem realizovány, eventuální využití jejich konceptu a vyhnutí se př́padným úskalím. Stejným směrem se ubíral i zde prezentovaný výzkum. Primární snahou bylo metodologicky obsáhnout jak kvantitativní, tak také kvalitativní formu paradigmatu, která nakonec vyústila ve volbu smíšené výzkumné 
strategie kombinující kvantitativní přístup párového srovnávání statických obličejových fotografií s kvalitativním př́stupem $\mathrm{v}$ podobě polostrukturovaných rozhovorü. Tato kombinace měla $\mathrm{v}$ prvé řadě přinést odpovědi na základní otázky o existenci/neexistenci společného konsensu v náhledu na atraktivitu stárnoucího obličeje mužů/žen a odhalit osobnostní rysy, sociální status a úroveň vzdělání, které respondenti dokáží stereotypně připisovat neznámému člověku, jehož tvář vnímají jako atraktivní ze statické obličejové fotografie. V jistém smyslu slova je možné tvrdit, že respondenti se $\mathrm{v}$ průběhu výzkumu ocitli v uměle vytvořené, „experimentální situaci“ a mně, coby výzkumníkovi, se tak zároveň naskytla př́ležitost pozorovat v této situaci jejich chování. Přestože pozorování jako technika sběru dat původně nebylo součástí metodologické triangulace, přineslo určitou "přidanou hodnotu“ v podobě interpretativních poznámek a osobních dojmů k výsledkům párového srovnávání a informacím získaným v průběhu polostrukturovaných rozhovorů.

Nejednalo se tedy o pozorování vědeckého charakteru, definované jako „technika sběru informací založená na zaměřném, systematickém a organizovaném sledování smyslově vnímatelných projevi a aktuálního stavu prvki̊, aspektů, fenoménů atd., které jsou objektem zkoumáni“ (Reichel 2009, s. 94). Vyjdeme-li ze vztahu mezi výzkumníkem (pozorovatelem) a respondenty (objekty pozorování) v experimentálních podmínkách výzkumu obličejové atraktivity, je možné charakter tohoto pozorování definovat jako zúčastněné, nestandardizované a skryté (Hendl 1999, s. 191-193; Reichel 2009, s. 94-97). Jinými slovy pozorovatel byl v tomto př́padě účastníkem situace, pozorování nebylo předem nikterak připravené ani formalizované a respondentům nebylo známo, že jsou výzkumníkem zároveň pozorováni.

\section{DƯVĚRYHODNOST VÝZKUMNÍKA - ÚČINNÁ ZBRAŇ PROTI ODMÍTNUTÍ}

Vzhledem k zaměření výzkumu na percepci obličejové atraktivity v kontextu stárnutí, byl dalším logickým krokem výběr a nafocení tváŕí jedinců ve věkovém rozmezí 50 - 65 let. Kde ovšem takové jedince „vzít“? Při kterých příležitostech se setkávají lidé tohoto věku, kteří se ochotně nechají vyfotografovat, přestože předem vědí, že bude posuzována jejich „atraktivita“? Současnou společností shodně vnímaná, vesměs negativní, zkušenost $s$ všudy přítomnými tazateli marketingových průzkumů či s vyplňováním různých dotazníků spokojenosti, byla podvědomou překážkou v oslovování případných aktérů tohoto výzkumu prímo na ulici. Jako schůdnější se nakonec ukázalo pořizovat fotografie během akcí pořádaných Západočeskou univerzitou v Plzni, jichž jsem, jako její zaměstnanec, pravidelnou součástí. Účast lidí př́islušné věkové kategorie byla předpokládána na dvou akcích. Jednalo se o přednáškový cyklus Fakulty zdravotnických studií ZČU s názvem „Den zdraví pořádaný pro účastníky Univerzity třetího věku a dále o „Dny vědy a techniky“. Na krku s visačkou ZČU prozrazující vedle mého jména také titul (MUDr.) a fakt, že jsem zástupce vedoucího jisté katedry, se „nábor“ dobrovolníků $\mathrm{k}$ fotografování značně usnadnil. Zároveň jsem pro účastníky „Dne zdravi“ byla lektorkou, která jim přednášela o pitném režimu, inkontinenci a funkci lymfatického systému, čímž byla má důvěryhodnost coby výzkumníka zajištěna.

\section{NÁBOR DOBROVOLNÍKU゚}

Strategie první etapy výzkumu byla jasná. Po vytipování těch správných příležitostí $\mathrm{k}$ „náboru“ aktérů př́ílušného věku, následovala př́íprava zázemí pro fotografování. $V$ případě „Dne zdraví, který se uskutečnil v prostorách Fakulty zdravotnických studií ZČU (tj. v místě mého každodenního působení), byla volba vhodného místa snadná. Po skončení přednášek se dobrovolníci shromáždili v jedné $\mathrm{z}$ učeben, kde byli nafoceni před staženým promítacím plátnem, které tak bylo zárukou světlého pozadí na výsledných fotografiích. Začínalo být zřejmé, že k naplnění pomyslné kvóty třiceti obličejových fotografí žen, by „Den zdravi“ plně postačoval. Nedostatek účastníků mužského pohlaví ovšem předurčil, že třicet fotografií mužských obličejů bude nutné získat $\mathrm{v}$ rámci druhé vybrané akce „Dny vědy a techniky“. Tato akce se pod záštitou ZČU každoročně odehrává v Plzni na Náměstí Republiky, přičemž většina fakult univerzity zde má svá stanoviště, na kterých se prezentují široké veřejnosti. Osobní zkušenost z předešlých ročníků mi dávala naději, že se mezi návštěvníky objeví například i dědečkové „vyslani““ na náměstí se svými vnoučaty. Vyzbrojena digitálním př́strojem Nikon D300s jsem byla připravena oslovit každého vhodného kandidáta, sdělit mu výzkumný účel případného použití fotografie jeho obličeje a po vyslovení souhlasu jej vyfotografovat před panelem bílé barvy, který je zde běžnou součástí expozic. Po dvou dnech strávených na náměstí se mi konečně podařilo vyfotografovat plánovaný počet třiceti fotografií mužů ve věku 50-65 let.

\section{MOŽNÉ DŮVODY K SOUHLASU S FOTOGRAFOVÁNÍM}

Je-li člověku přes padesát a někdo mu prostě sdělí, že právě jeho obličej je vhodný k nafocení za účelem výzkumu atraktivity, první, co ho nejspíše napadne, je, že si z něj ten „někdo“ dělá legraci. Vyvolat takový pocit u př́ípadných dobrovolníků hned zpočátku je nejen neštastné, ale také proti všeobecným principům výzkumné etiky. Jak se dočítáme v Etickém kodexu Anthropictures přijatém 1. února 2013: „Praktikanti antropologického výzkumu mají základní etické povinnosti vůči lidem,(...) které studují; jejich etickou povinností je rovněž predjímat a predcházet újmè, křivdě a ublížení a zároveň „v rámci procesů prípravy, formulace a realizace výzkumu, musí být otevření ohledně svých výzkumných zámèrü“."

1 Etický kodex Anthropictures. (online) http://www.anthropictures.cz/wp-content/uploads/2013/03/Etick\%C3\%BD_kodex_Anthropictures.pdf 
Většina lidí v tomto věku si o sobě nemyslí, že by byli atraktivní, jelikož podléhají všeobecné představě o tom, že atraktivita je spíše atributem mládí (Thornhill, Gangestad 1999, s. 458). V tom se shodují (mají-li na mysli atraktivitu fyzickou) i s teoriemi pocházejícími z ranku evoluční biologie, která se v současné době výzkumem fyzické atraktivity obličeje zabývá nejvíce a $\mathrm{v}$ níž dominují pojmy jako mládí, plodnost a reprodukce vztahující se zejména k výběru potenciálního partnera (Thornhill, Gangestad 1999, s. 452). Existuje ale i jiné prizma, jímž je možné na obličejovou atraktivitu pohlížet, a tím je sociální psychologie, která atraktivitu definuje následovně: „Atraktivita se vztahuje $k$ jedinci nebo skupině osob, jejichž nějaká vlastnost či vlastnosti jsou pro jiné jedince zdrojem odměn. Fyzické a osobní vlastnosti vyvolávají prímou nebo kognitivními procesy zprostředkovanou pozitivní emoční odezvu a nositelé těchto vlastností mohou uspokojovat nejrůznější potřeby těch, pro které jsou přitažliví." (Slaměník, Výrost 2008, s. 252) Dobrovolníkům bylo tedy nejprve vysvětleno, že i stárnoucí obličej může v ostatních vyvolávat pozitivní emoce a tím je prítahovat, což je ve své podstatě vysvětlení původního významu slova atraktivita, odvozeného $\mathrm{z}$ latinského at-trahere (prritahovati). Takové vysvětlení ovšem vyžaduje čas a především důvěryhodnost výzkumníka, kterou jsem se již od počátku snažila objektivizovat výběrem vhodných př́ležitostí v podobě akcí pořádaných pod záštitou Západočeské univerzity. Z časového hlediska bylo mnohem jednodušší vysvětlit svůj záměr všem najednou, což se podařilo pouze v prŕpadě první akce s názvem „Den zdraví. Jak již bylo dřive řečeno, této akce se zúčastnily především ženy, které byly rovněž „studentkami“ Univerzity třetího věku. Jejich přístup byl otevřený, vítaly další př́íležitost se v něčem vzdělat a možná, že jejich ochota se fotografovat, byla i tak trochu poděkováním. Muži byli foceni v průběhu „Dnů vědy a techniky“, tedy v době, kdy celé město předpokládá, že příchodem na náměstí se dozví něco nového. I když tam muži přicházeli s představou, že opět uvidí nějaké novinky spíše technického charakteru, brali focení jako součást veškerého dění, moc se o důvody nezajímali, nechali se vyfotografovat a spěchali k dalším expozicím v sousedství představujícím laserové technologie, 3D tisk či virtuální realitu.

\section{ZAUJMOUT NEUTRÁLNÍ VÝRAZ - „META“, KTERÉ SE VE VYŠŠÍM VĚKU NEDAŘÍ DOSÁHNOUT}

Valná většina prací, stř̌edem jejichž zájmu je obličejová atraktivita, využívá k jejímu hodnocení statické obličejové fotografie žen/mužů (respondentům neznámých), přičemž jedním ze základních požadavků na fotografie kladených, je také neutrální výraz obličeje nafocený z pohledu „en face“ a přímý pohled do objektivu. (Langlois et al. 2000, Otta et al. 1996, Penton-Voak 2008) Požadavek související s neutrálním výrazem je z hlediska hodnocení obličejové atraktivity pochopitelný, nebot výraz jakékoliv emoce může dojem atraktivity ovlivnit $\mathrm{v}$ pozitivním, ale také negativním smyslu.

Všichni účastníci byli nejprve vyzváni k odložení brýlí, k př́imému pohledu do objektivu a udržení neutrálního výrazu po dobu fotografování. Ani jeden z výše uvedených požadavků se, alespoň mně, nezdál být nemožný. Odložit si brýle, hledět zpříma do objektivu a tvářit se klidně a vyrovnaně, přeci nemůže být takový problém. Ukázalo se ovšem, že udržet neutrální výraz, ze kterého nelze vyčíst žádné emoce, a dívat se do objektivu přímo, jsou pro řadu lidí tohoto věku překážkou, kterou si sami ani neuvědomují. Přes veškerou snahu a opakované požádání o nastolení neutrálního výrazu, se tento požadavek u většiny dobrovolníků nepodařilo splnit bezezbytku a $\mathrm{v}$ podstatě každý $\mathrm{z}$ obličejů naznačoval více či méně nějakou emoci. Zpočátku jsem si říkala, že fotografie vyjadřující určité emoce bude možné $\mathrm{z}$ výzkumu následně eliminovat už jen $\mathrm{z}$ důvodu plánovaného využití programu Anthropac k párovému srovnávání, ve kterém je nejefektivnější použít deset fotografií pro každé pohlaví. Tento program, využívaný zejména v kognitivní antropologii, měl posloužit k vygenerování dotazníků s jednotlivými „obličejovými páry“. Aby byla zachována poměrná časová nenáročnost při jejich administraci $\mathrm{v}$ rámci následného výzkumu, kterého se mělo zúčastnit sto dvacet respondentů, bylo nutné $\mathrm{z}$ původních třiceti fotografií žen a třiceti fotografií mužů vybrat jen deset od každého pohlaví. Pokud by bylo použito původních třicet fotografií, objevilo by se $\mathrm{v}$ jednom dotazníku 460 různých kombinací párů, což z hlediska udržení pozornosti hodnotitele nebylo proveditelné. Jako únosný se zdál počet 45 párových kombinací na jednoho respondenta, čehož bylo dosaženo užitím jen deseti obličejových fotografií. Nejprve byl každý ze souborů zredukován na polovinu (15) vyřazením fotografií, které nebyly dostatečně kvalitní a těch, kde byly obličeje př́liš vrásčité. O eliminaci zbylých pěti fotografií rozhodlo následně deset dobrovolníků, kteří se dalšího výzkumu neúčastnili a jejichž úkolem bylo vybrat typově podobné obličeje a náhodným výběrem některé z nich vyloučit. Ukázalo se, že ani po proběhlé redukci se na zbylých deseti fotografiích neobjevoval neutrální výraz bez náznaku jistých emocí.

Chtít po lidech, kteří se při své cestě životem naučili stereotypně užívat určitý typ výrazu nejčastěji, aby se tvářili neutrálně, se ukázalo jako požadavek, který při hodnocení stárnoucích obličejů nemůže být naplněn. Jedním $\mathrm{z}$ charakteristických rysů stárnoucího obličeje je přeměna tzv. dynamických vrásek, které vznikají kontrakcí (stahováním) mimických svalů, do podoby vrásek statických, tedy jakýchsi neměnných záhybů kůže zasahujících do jejích hlubších vrstev. Tento úzký vztah mezi aktivitou mimických svalů a tvorbou vrásek evokuje také představu o tom, že během života častěji užívaný mimický výraz (at již pod vlivem aktuálně prožívaných emocí, nebo hraný v rámci sociálních postojů) se může charakteristickými druhy vrásek „vtisknout“ do stárnoucího obličeje a „neutrálním“ výrazem je pak výraz užívaný během života nejčastěji (Malatesta, Fiore, Messina 1987, s. 64; Hess et al. 2012, s. 1377).

\section{VÝBĚROVÝ SOUBOR}

Při konstrukci výzkumného vzorku (výběrového souboru) respondentů, jejichž náhled na obličejovou atraktivitu v kon- 
OBYVATELSTVO

POPULATION

4-3. Složení obyvatelstva podle pohlaví a věkových skupin v roce 2012

Distribution of the population by sex and age group in 2012

\begin{tabular}{|c|c|c|c|c|c|c|c|c|c|}
\hline \multirow{3}{*}{$\begin{array}{c}\text { Věk } \\
\text { Age (years) }\end{array}$} & \multicolumn{3}{|c|}{1 January } & \multicolumn{3}{|c|}{ 1. 7.} & \multirow{3}{*}{$\begin{array}{l}\text { 31. } 12 . \\
\text { celkem } \\
\text { Total }\end{array}$} & \multicolumn{2}{|c|}{31 December } \\
\hline & celkem & muži & ženy & celkem & muži & ženy & & muži & ženy \\
\hline & Total & Males & Females & Total & Males & Females & & Males & Females \\
\hline $\begin{array}{c}\text { Celkem } \\
\text { Total }\end{array}$ & 10505445 & 5158210 & 5347235 & 10509286 & 5160913 & 5348373 & 10516125 & 5164349 & 5351776 \\
\hline 0 & 108753 & 55809 & 52944 & 108724 & 55696 & 53028 & 108692 & 55576 & 53116 \\
\hline $1-4$ & 481937 & 246478 & 235459 & 477435 & 244358 & 233077 & 473008 & 242248 & 230760 \\
\hline $5-9$ & 497702 & 255816 & 241886 & 510235 & 262062 & 248173 & 522828 & 268298 & 254530 \\
\hline $10-14$ & 452849 & 232831 & 220018 & 454329 & 233659 & 220670 & 455768 & 234407 & 221361 \\
\hline $15-19$ & 541105 & 277548 & 263557 & 525652 & 269545 & 256107 & 510265 & 261554 & 248711 \\
\hline $20-24$ & 671462 & 343291 & 328171 & 665681 & 340159 & 325522 & 660086 & 337096 & 322990 \\
\hline $25-29$ & 721200 & 371423 & 349777 & 716212 & 368849 & 347363 & 711493 & 366360 & 345133 \\
\hline $30-34$ & 847314 & 436174 & 140 & 829982 & 427313 & 69 & 13 & 32 & 394481 \\
\hline $35-39$ & 918039 & 471945 & 446094 & 927123 & 476482 & 641 & 936824 & 481286 & 455 \\
\hline $40-44$ & 718925 & 369407 & 349518 & 732182 & 376219 & 355963 & 745793 & 383187 & 362606 \\
\hline $45-49$ & 705709 & 360052 & 345657 & 707892 & 361430 & 346462 & 710290 & 362884 & 347406 \\
\hline $50-54$ & 649679 & 326608 & 323071 & 641946 & 323120 & 318826 & 634324 & 319634 & 314690 \\
\hline $55-59$ & 745595 & 365375 & 380220 & 738158 & 362183 & 375975 & 730876 & 359007 & 371869 \\
\hline $60-64$ & 743740 & 353999 & 389741 & 739368 & 352318 & 387050 & 735147 & 350625 & 384522 \\
\hline $65-69$ & 595116 & 270918 & 324198 & 615428 & 280574 & 334854 & 635869 & 290217 & 345652 \\
\hline $70-74$ & 402749 & 173096 & 229653 & 413128 & 177994 & 235134 & 423602 & 182877 & 240725 \\
\hline $75-79$ & 307188 & 120556 & 186632 & 304557 & 119877 & 184680 & 301966 & 119173 & 182793 \\
\hline $80-84$ & 234820 & 81828 & 152992 & 236407 & 82848 & 153559 & 238033 & 83879 & 154154 \\
\hline 85-89 & 124404 & 36168 & 88236 & 125239 & 36711 & 88528 & 126082 & 37253 & 88829 \\
\hline $90-94$ & 31495 & 7734 & 23761 & 34219 & 8417 & 25802 & 36938 & 9102 & 27836 \\
\hline $95+$ & 5664 & 1154 & 4510 & 5389 & 1099 & 4290 & 5128 & 1054 & 4074 \\
\hline $0-14$ & 1541241 & 790934 & 750307 & 1550723 & 795775 & 754948 & 1560296 & 800529 & 759767 \\
\hline $15-64$ & 7262768 & 3675822 & 3586946 & 7224196 & 3657618 & 3566578 & 7188211 & 3640265 & 3547946 \\
\hline $65+$ & 1701436 & 691454 & 1009982 & 1734367 & 707520 & 1026847 & 1767618 & 723555 & 1044063 \\
\hline
\end{tabular}

Tab. 1. Složení obyvatelstva podle pohlaví a věkových skupin v roce 2012; Pramen: Statistická ročenka České republiky 2013 (online)

textu stárnutí by mohl předpovídat náhled v rámci cílové populace (základního souboru), se jako nejvhodnější strategie zdálo v první fázi použití kvótního výběru, kdy jako kvóty byly zvoleny dva znaky - pohlaví a věková kategorie. Za cílovou populaci (základní soubor) byl zvolen soubor mužů a žen české národnosti v souhrnném věkovém rozmezí 20-65 let, jehož velikost dle demografických údajů k 31. 12. 2012 činila 4284969 lidí (tab. 1).

Vlastní kvantitativní oporou pro tento údaj byla „Statistická ročenka České republiky 2013“ volně přístupná na webových stránkách Českého statistického úřadu. ${ }^{2}$ Pokud bychom se striktně drželi regulí kvantitativního výzkumu, bylo by

2 http://www.czso.cz/csu/2013edicniplan.nsf/publ/0001-13-r_2013 pro zajištění dostatečné reprezentativity výběrového vzorku na místě, alespoň podle sociologického úhlu pohledu, oslovit 2571 respondentů ve věkové kategorii 20-65 let, což by odpovídalo 0,06\% cílové populace (srov. Katriak 1975), která, jak již bylo zmíněno, dle údajů statistické ročenky dosahovala k 31.12.2012 absolutního počtu 4284969 lidí. Takový cíl zdál se poněkud nedosažitelný, už jen z hlediska časové tísně, kterou doktorské studium, $\mathrm{v}$ rámci něhož byl výzkum realizován, přináší. $\mathrm{K}$ zajištění reprezentativity výběrového vzorku by tak teoreticky vedly dvě cesty. Dlouhodobý lineární výzkum nebo on-line způsob dotazování. Ani jedna z nich však nebyla schůdná, at již pro časovou náročnost v prvém případě, nebo absenci výzkumníka v př́padě druhém. Únosným se nakonec zdál celkový počet 120 respondentů. 
S odvoláním na Jeřábka (1992), který tvrdí, že „výběrový soubor nikdy nereprezentuje základní soubor přsně“ (Jeřábek 1992, s. 42), nezbývá než doufat, že k zajištění reprezentativity byla alespoň co nejpřesněji vymezena homogenní populace a výběr byl proveden natolik adekvátně, že jeho chyba (chyba výběru) byla náhodná, tj. taková, která se nebude měnit při př́padném opakovaném šetření na dalších stejně velkých výběrových souborech $(\mathrm{N}=120)$. Pro získání stanovené velikosti výzkumného vzorku respondentů byla následně užita technika stratifikovaného náhodného výběru, přičemž respondenti byli vybíráni ze čtyř podskupin (strat) základního souboru prostým náhodným výběrem $\mathrm{v}$ poměrovém zastoupení $25 \%$ (30) respondentů z každého $\mathrm{z}$ nich (srov. tab. 2).

\begin{tabular}{|c|c|c|c|}
\hline $\begin{array}{c}\text { věková } \\
\text { kategorie }\end{array}$ & muži & ženy & celkem \\
\hline $20-35$ & $\begin{array}{c}1122088 \\
(51 \%)\end{array}$ & $\begin{array}{c}1062604 \\
(49 \%)\end{array}$ & $\begin{array}{c}2184622 \\
(100 \%)\end{array}$ \\
\hline $50-65$ & $\begin{array}{c}1029266 \\
(49 \%)\end{array}$ & $\begin{array}{c}1071081 \\
(51 \%)\end{array}$ & $\begin{array}{c}2100347 \\
(100 \%)\end{array}$ \\
\hline $20-65$ & $\begin{array}{c}2151354 \\
(50 \%)\end{array}$ & $\begin{array}{c}2133685 \\
(50 \%)\end{array}$ & $\begin{array}{c}4284969 \\
(100 \%)\end{array}$ \\
\hline
\end{tabular}

Tab. 2. Zastoupení mužů a žen ve věkových kategoriích 20-35 a 50-65 let; Upraveno podle: „Statistická ročenka České republiky 2013“ (online)

Vlastní výzkum probíhal osm měsíců v období od června 2012 do ledna 2013. Každému jednotlivému respondentovi byl nejprve přidělen identifikační kód (ID), pod kterým byl dále ve výzkumu veden, a to podle následujícího klíče: $\mathrm{R}$ respondent, $\mathrm{M}$ - muž, $\mathrm{Z}$ - žena, $\mathrm{M}$ - mladší, $\mathrm{S}$ - starší. Takto vznikly čtyři podskupiny hodnotitelů, každá o třiceti účastnících (RMM01-RMM30; RZM01-RZM30; RMS01-RMS30; RZS01-RZS30). V rámci jednotlivého setkání, které probíhalo 20 až 30 minut, byl nejprve každý informován o zachování anonymity. Po krátkém dotazování na proměnné typu věk, rodinný status, městský/venkovský typ, antikoncepce - $\mathrm{ANO} /$ $\mathrm{NE}$, menopauza - ANO/NE, probíhalo vlastní párové srovnávání s využitím dotazníkủ v powerpointových prezentacích (obr. 1) následované polostrukturovaným rozhovorem.

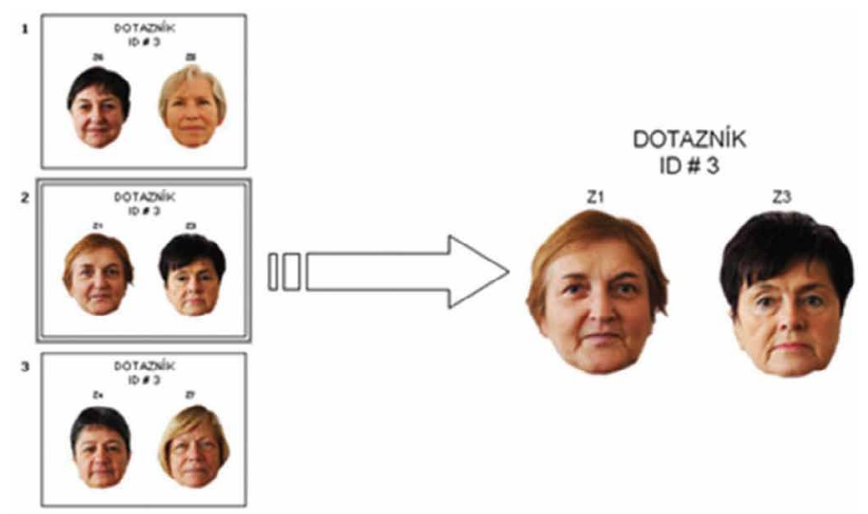

Obr. 1 Ukázka výsledné powerpointové prezentace dotazníku s vloženými obličejovými fotografiemi; Zdroj: autorka

\section{MUŽSKÝ VS ŽENSKÝ PŘÍSTUP K HODNOCENÍ}

Jak výzkum plynul, začínalo být postupně jasné, že hodnotit stárnoucí obličeje $\mathrm{z}$ hlediska atraktivity, je pro respondenty nepřirozené a jejím ekvivalentem se $\mathrm{v}$ tomto věku stávají sympatie. Respondenti bud' reagovali již na prvotní instrukci „vyberte, prosím, $z$ každého páru pro vás atraktivnější obličej" dotazem .....,Myslite sympatičtěǰší, ne?" anebo po skončení párového srovnávání uvedli ...,vždy jsem si predstavil/a, $k$ do na mě působi sympatičtěji“' Jak uvádí I. Slaměník: „V našich kulturních podminkách i v odborné psychologické literature je sympatie chápána jako citlivá náklonnost, pozitivní vztah $k$ někomu či něčemu a má blízko k atraktivitě" (Slaměník, 2011, str. 137).

$\mathrm{V}$ př́ípadě starších respondentů ve věkovém rozmezí 50-65 let bylo rovněž zajímavé skrytě pozorovat jejich chování při rozhodování se o tom, která z fotografií se jim jeví jako sympatičtější. Na rozdíl od mužủ, ženy $k$ hodnocení přistupovaly s jasnou představou. Muž tohoto věku má mit vlasy, být hladce oholen, měl by sportovat, mít dobré postaveni $v$ zaměstnání. Může být i trochu záletník, ale zároveň rodinný typ, který se o svou rodinu stará a nedá na ni dopustit. Toto všechno ovšem završuje tvrzení, které se $\mathrm{v}$ průběhu následných polostrukturovaných rozhovorů s ženami objevovalo v souvislosti s nejsympatičtějším mužem nejvíce: "Je o něj dobře postaráno". $\mathrm{V}$ př́padě žen (v podstatě ve stejné věkové kategorii jako samy respondentky) byly tyto $\mathrm{v}$ hodnocení mnohem náročnějš́. Za nejsympatičtější označily tvár ženy s vyčesanými vlasy dozadu, odhaleným vysokým čelem s téměř žádnými vráskami, upraveným obočím, tvář, která byla pravděpodobně udržována pravidelnými kosmetickými zásahy. Starší respondentky tuto ženu obdivovaly a chtěly by vypadat jako ona. Pouze žena, která o sebe pečuje a snaží se udržovat mladistvý vzhled, může být podle jejich názoru vnímána jako sympatická. Jakoby ony samy podporovaly přeživání „mýtu krásy“ a podvolovaly se tak kulturnímu imperativu mladistvého vzhledu.

Zcela odlišnou cestou se výzkum ubíral v případě starších respondentů mužského pohlaví. Za nejsympatičtějǐí považovali ženu, ve které vidí „bezproblémového př́tele“, se kterou by podle svých slov „šli na pivo“, která je férová, obětavá, pracovitá, nekonfliktní, chytrá, hodná a sportovnè založená. Není tedy divu, že jako nejsympatičtější označili zcela odlišnou tvář, nežli respondentky. Pokud ovšem někteří z nich označili za nejsympatičtější obličej stejné ženy, jaká zvítězila v př́ípadě respondentek, hodnotili ji poněkud povrchněji jako ,ženu pracháče", pěstěnou, po plastické operaci, jako ženu emancipovanou, žijící ve vile, ženu, která si „ jde za svým“ a které „dělají chlapi dobře". Muži jakoby se jejích sympatií obávali s pocitem, že by jim mohla být nevěrná a že by takovou ženou byli „tlačeni“ $\mathrm{k}$ vyšším výdělkům.

Samostatnou kapitolou by pak mohla být ta část výzkumu, ve které starší respondenti hodnotili muže stejné věkové kategorie. Budto za nejsympatičtějšího označili toho, o kterém se podle svých slov domnívali, „že se líbí ženám" a na konci výzkumu s velkým údivem přijali informaci, že právě tento muž byl ženami často označován jako nejméně sympatický, anebo byli v hodnocení velmi váhaví a bylo patrné (obzvláště, 
pokud výzkum probíhal u manželských párů a manželka byla ve vedlejší místnosti), že by ocenili radu svého protějšku. Většina $\mathrm{z}$ nich tvrdila, že ,hodnotit muže je pro ně mnohem těžší a méně prirozené nežli hodnotit ženy“.

Při provádění výzkumu u manželských párů, což byla z mé strany strategie, kdy jsem při jedné návštěvě získala dva respondenty najednou, se objevil ještě jeden zajímavý aspekt, který výzkum provázel - manželská výměna názorů. Po skončení výzkumu byli většinou oba zvědavi na to, jak hodnotil ten druhý a zdali se ve svém úsudku shodují. Po mnohaletém soužití se také několikrát stalo, že muž jako nejsympatičtější označil ženu, která se typově naprosto neshodovala s manželkou, a jejich následné dohadování mě odhalilo příčinu, proč přístup mužů ve výzkumu byl zpočátku tak váhavý i v př́padě hodnocení žen.

Získat pro výzkum respondenty mladší věkové kategorie, bylo, vzhledem $\mathrm{k}$ mému působení v roli odborného asistenta na vysoké škole, mnohem schůdnější. Každoročně přednáším humánní anatomii a farmakologii studentům v celkovém počtu kolem 250 a ochota některých $\mathrm{z}$ nich ke spolupráci pramenila možná také z jistého uspokojení, že jsme si na chvíli rovni, nebot' i já, coby jejich přednášející a zkoušející, jsem zároveň studentem, i když s poněkud vyšší aspirací $(\mathrm{PhD})$ nežli $\mathrm{v}$ danou chvíli oni (Bc.).

Mladší respondentky sympatie přisuzovaly mužům, kteří na ně působili jako „hodný dědeček“, „kamarádský táta“, jako člověk, který „má rád vnoučata“, i když se se svými dětmi hádá, „má rád zviřata“ nebo je učitelem, který se „věnuje žákưm i po vyučováni“. Do tváře nejsympatičtější ženy si dívky promítaly roli zdravotní sestry či lékařky, která „to umí s dětmi“, „pracuje s lidmi“, je vzdělaná, hodná, inteligentní, citlivá a „lidé ji mají rádi“. Mladé ženy viděly sympatie žen vyššího věku spiše než v kráse, ve „schopnosti s nimi dobře vyjít i pres jejich mládi“.

Obdobně i mladší respondenti za sympatické považují muže, ve kterých vidí „oblíbeného tátu“ či „kouzelného, hodného a správného dědu“. Zároveň je jim v tomto věku sympatický muž, který „se nad nikým nepovyšuje“, „není kariérista ani arogantni", který chalupaři, rybaří a „trénuje mládež fotbal“. O nejsympatičtější ženě si mladší respondenti vytvářejí obraz typické učitelky, zdravotní sestry či sociální pracovnice, tedy obraz role, ve které by rádi, aby ve společnosti vystupovala. Představují si tak ženu, která by je měla vzdělávat a ošetřovat, jinak řečeno nejsympatičtější je pro ně v tomto věku žena, která o ně bude dobřre pečovat.

\section{SHRNUTÍ}

Výzkum atraktivity lidského obličeje je postaven především na mezipohlavním hodnocení statických fotografií mladších jedinců ( $\mathrm{v}$ průměru kolem 25 let) a to ve vztahu $\mathrm{k}$ reprodukci a výběru potenciálního partnera. Pưvodně odvážné zaměření výzkumu obličejové atraktivity na stárnoucí jedince sice potvrdilo jistou nepřrirozenost ve spojování stárnutí s atraktivitou, ale zároveň ukázalo, že jejím ekvivalentem jsou ve vyšším věku sympatie, které mají podle sociálních psychologů k atraktivitě velmi blízko.
Úspěch při náboru starších dobrovolníků $\mathrm{k}$ nafocení jejich obličejů je možné jednoznačně připisovat důvěryhodnosti výzkumníka objektivizované statutem vysokoškolského pedagoga. Jistým limitem bylo při fotografování udržení neutrálního výrazu vzhledem $\mathrm{k}$ přítomnosti vrásek, které $\mathrm{v}$ tváŕích imitovaly $\mathrm{v}$ průběhu života nejčastější emoční výraz. Požadavek neutrálního výrazu u stárnoucích jedinců sice nebylo možné dodržet, ale možná právě náznak nějaké emoce ukazoval na předchozí emoční život jedince a tím u respondentů bud' vzbuzoval sympatie či nikoliv.

U mladších respondentů lze bez ohledu na pohlaví vypozorovat určitý společný rys vycházející ze sociální role, kterou v této věkové kategorii ve společnosti zastávají. Za sympatické tak shodně označují obličeje, do kterých si promítají rodiče či prarodiče, kteří to s nimi umí, nezávidí jim jejich mládí, pečují o ně, ochraňují je a vzdělávají. V případě starších respondentů je ovšem zřetelný rozdíl $v$ náhledu na sympatie mezi ženami a muži. Zatímco respondentky mají jasný názor na to, že žena o sebe musí pečovat a udržovat si mladistvý vzhled co nejdéle, aby mohla být ostatními považována za sympatickou, muži vidí sympatie stárnoucích žen v nekonfliktnosti a bezproblémovém přátelství. V pozadí mužských sympatií pak ženy často hledají opět ženy, které o takové muže dobře pečují. A co říkají muži na sympatie obličejů stejného věku a pohlaví? V podstatě bez názoru tápají, nemohou se rozhodnout, a pokud se již odhodlají k úsudku, volí muže, o kterém se domnívají, že se líbí ženám.

\section{LITERATURA}

Etický kodex Anthropictures. (online) http://www.anthropictures.cz/wp-content/uploads/2013/03/Etick\%C3\%BD_kodex_Anthropictures.pdf

Hendl, Jan (1999): Úvod do kvalitativního výzkumu. 1. vyd. Praha: Karolinum.

Hess, Ursula, Adams, Reginald B., Simard, Annie, Stevenson, Michael T., Kleck, Robert E. (2012): Smiling and sad wrinkles: Age-related changes in the face and the perception of emotions and intentions. Journal of Experimental Social Psychology, 48, 1377-1380.

Jeřábek, Hynek (1993): Úvod do sociologického výzkumu. 1. vyd. Praha: Univerzita Karlova.

Katriak, Martin (1975): Metódy a techniky sociologického výskumu. Bratislava: Veda.

Langlois, J. H. - Kalakanis, L. E. - Rubenstein, A. J. - Larson, A. D. - Hallam, M. J. - Smoot, M. T. (2000): Maxims or Myths of Beauty? A Meta-Analytic and Theoretical Review. Psychological Bulletin, 126, 390-423.

Malatesta, C. Z. - Fiore, M. J. - Messina, J. J. (1987): Affect, personality, and facial expressive characteristics of older people. Psychology and Aging, Vol 2(1), 64-69.

Otta, E. - Abrosio, F. F. E. - Hoshino, R. L. (1996): Reading a smiling face: Messages conveyed by various forms of smiling. Perceptual and Motor Skills, 82, 1111-1121.

Penton-Voak, I. S. - Chang, H. (2008): Attractiveness judgments of individuals vary across emotional expression and movement conditions. Journal of Cultural and Evolutionary Psychology, 6, 89-100.

Reichel, Jiří (2009): Kapitoly metodologie sociálních výzkumů. 1. vyd. Praha: Grada Publishing, a. s.

Slaměník, Ivan, Výrost, Jozef (2008): Sociální psychologie 2., přepracované a doplněné vydání Praha: Grada Publishing.

Slaměník, Ivan (2011): Emoce a interpersonální vztahy. Vyd. 1. Praha: Grada Publishing.

Thornhill, Randy, Gangestad, Steven W. (1999): Facial attractiveness. Trends in Cognitive Sciences, 1364-6613, 452-460.

(online) http://www.czso.cz/csu/2013edicniplan.nsf/p/1409-13 


\section{AUTORKA}

Pavlíková, Lada (1969) působí jako odborný asistent na Katedře teoretických oborů Fakulty zdravotnických studií ZČU v Plzni a zároveň je doktorandkou na Katedře antropologie Filozofické fakulty ZČU v Plzni, kde se věnuje výzkumu percepce lidského obličeje $\mathrm{s}$ ohledem na atraktivitu a proces stárnutí. $\mathrm{V}$ minulých letech půso- bila jako odborná asistentka na Ústavu anatomie Lékařské Fakulty UK v Plzni a jako lektorka anatomie na University of Leeds, Faculty of Biological Sciences, Institute of Membrane and Systems Biology, United Kingdom.

Kontakt: MUDr. Lada Pavlíková, Katedra antropologie Fakulty filozofické Západočeské univerzity v Plzni, Sedláčkova 15, 30614 Plzeň, e-mail: lada.pavlikova@seznam.cz 
